\title{
The deep sea elements of the Faroe Bank tardigrade fauna with a description of two new species
}

\author{
Jesper GULDBERG HANSEN
}

Department of Invertebrate Zoology, Zoological Museum, University of Copenhagen, Universitetsparken 15, DK-2100 Copenhagen, Denmark

e-mail: jehansen@snm.ku.dk

\begin{abstract}
Two new marine Tardigrada species are described from the calcareous sediments at the steep slope of the Faroe Bank in the North Atlantic Ocean. Parmursa torquata sp. nov. can be distinguished mainly by small cylindrical secondary clavae, and the presence of caudal and cephalic vesicles, and a large ventral plate. Coronarctus verrucatus sp. nov. is characterised by its unique cuticular sculpture, with numerous small wart-like excrescences, regularly distributed all over the body. These new records from the relatively shallow water of the Faroe Bank (200-260 m) further widen the range of Parmursa and Coronarctus distribution and diversity, especially regarding the genus Parmursa, which to date has remained monospecific.
\end{abstract}

Key words: Tardigrada, Arthrotardigrada, Faroe Bank, Parmursa torquata sp. nov, Coronarctus verrucatus sp. nov.

\section{INTRODUCTION}

Although deep-sea tardigrades have been known since the mid-1960's, the published information is scattered and data about their worldwide distribution are still very scarce. This study adds yet another piece to the puzzle of deep-sea tardigrades. Since the erection of Parmursa Renaud-Mornant, 1984 and the addition of four new species to the genus Coronarctus by RenaudMornant in 1987, no further species have been ascribed to either of these bathyal and abyssal genera. Among the collections gathered during the BIOFAR programme in the North Atlantic Sea (Kristensen 1992, 1999; Hansen et al. 2001; Hansen 2005), new species of both Parmursa and Coronarctus were found.

\section{METHODS}

The new species from the Faroe Bank was encountered during expeditions in 1990, 1992 and 1998. BIOFAR Station 627 was sampled by the German R/V Valdivia (1990), BIOFAR Station 785 was sampled by the Faroese Coast Guard vessel Olavur Halgi (1992) and BIOFAR Station 2011 was sampled by R/V Magnus Heinason of the Faroese Fishery Investigations (1998). Details on the sampling-localities are provided in Nørrevang et al. (1994). To release the tardigrades from the sediment, a number of sub-samples at each station were fresh-water shocked, decanted through a $32 \mu \mathrm{m}$ mesh net and fixed in $4 \%$ buffered formaldehyde for later sorting. Specimens were mounted on micro slides in glycerol and studied using phase-contrast and Nomarski-technique (DIC). A single specimen of each species was prepared for scanning electron microscopy (SEM). They were dehydrated in a graded series of ethanol and acetone prior to critical point drying. The dehydrated specimens were then mounted on aluminium stubs, coated with gold and observed in a JEOL JSM840 scanning electron microscope. The type-material is deposited in the collections of the Zoological Museum, Copenhagen (ZMUC), Denmark. In addition to the examination of two paratypes (AR 316 and AR 317) of Parmursa fimbriata Renaud-Mornant, 1984, this study also includes the examination of a single specimen of Parmursa sp. collected at $1813 \mathrm{~m}$ depth from Lihir Island in the New Ireland Basin, by the German FS Sonne (Herzig 1998). This species cannot be attributed to either P. fimbriata or Parmursa torquata sp. nov.; however a detailed description awaits the finding of further specimens of this particular species.

Abbreviations: an: anus, ap: apophysis, bt: buccal tube, ca: caudal ala, cB-E: cirrus B-E, cg: claw gland, ec: external cephalic cirrus, go: gonopore, gu: midgut, ic: internal cephalic cirrus, lc: lateral cirrus, ma: muscle attachment, mc: median cirrus, mo: mouth cone, mu: muscle, pb: pharyngeal bulb, pc: primary clava, pl: placoid, pv: ventral plate, rs: seminal receptacle, sc: secondary clava, se1-4: sense organ of leg 1-4, sp4: spine-like projection of leg 4, st: stylet, te: testis, sv: seminal vesicle, v.ca: caudal vesicle, v.ce: cephalic vesicle.

\section{RESULTS}

\subsection{Family Halechiniscidae Thulin, 1928}

Diagnosis: Arthrotardigrades without sclerotised dorsal segmental plates. The complete set of cephalic appendages in halechiniscids is 11 , but the secondary clavae may be indistinguishable (9) or a pair of tertiary clavae may be present (13). Each adult leg with four 


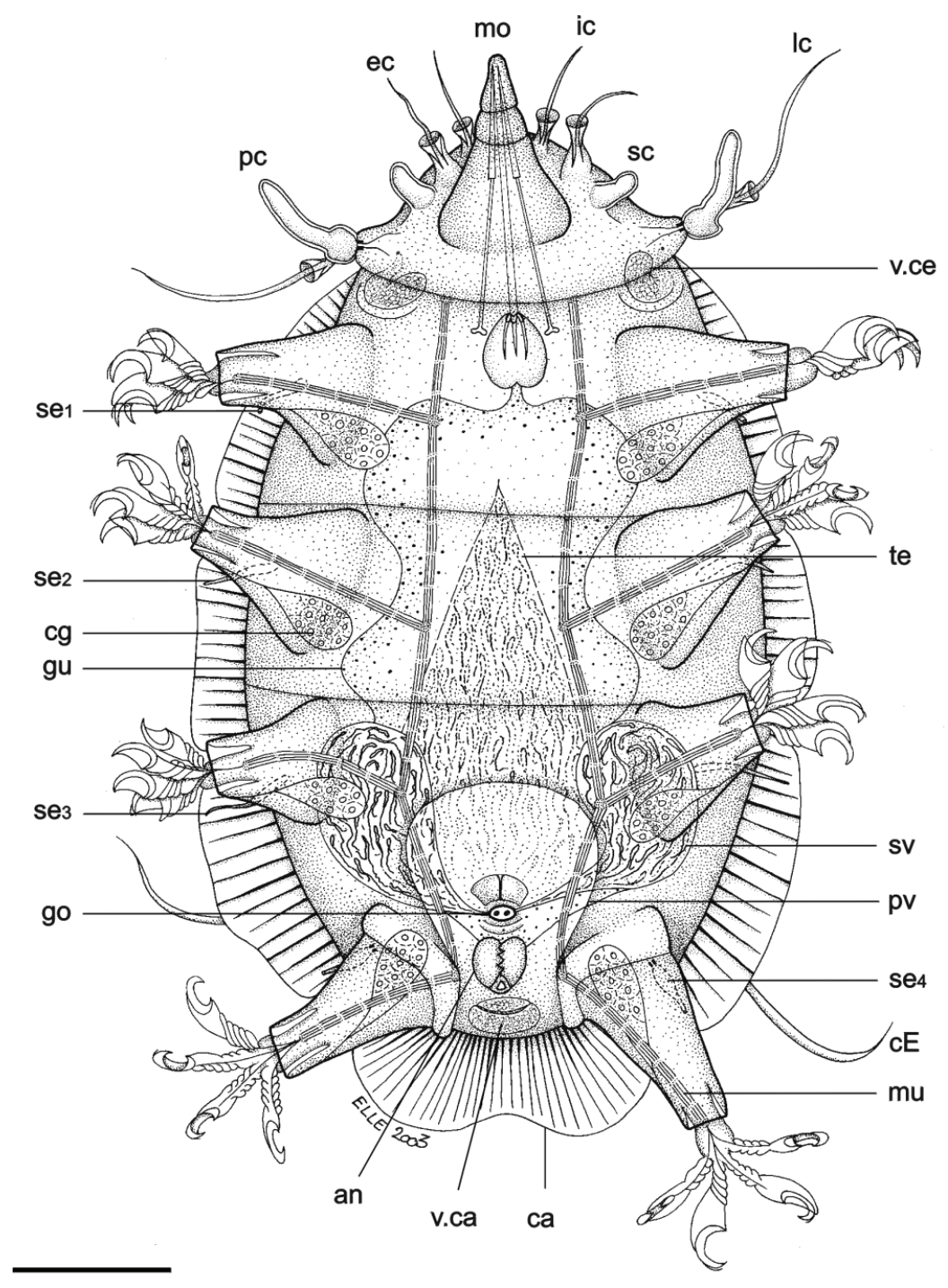

Fig. 1. Parmursa torquata sp. nov.: adult holotypic male, ventral view. Scale bar $=25 \mu \mathrm{m}$. Drawing by Stine B. Elle.

digits with claws. Claws simple or with accessory hooks, spurs or thin bristles. Peduncles can be present on all digits or only on external digits. Two cuticular seminal receptacles always present in adult females.

\subsection{Subfamily Euclavarctinae Renaud-Mornant, 1983}

Halechiniscidae with unplated body without projections. Conical head bearing two sets of unequally shaped clavae. Cirri A and primary clavae are inserted separately. The claws are simple or with dorsal spur on internal digits.

Type genus: Euclavarctus Renaud-Mornant, 1975.

\subsection{Genus Parmursa Renaud-Mornant, 1984}

Diagnosis (emended): Euclavarctinae with cuticular aliform expansions supported externally by dorsal cuticular ribs. Trapezoid head, completely proportionate to the arrangement of the cephalic sense organs.
Cephalic cirri with a funnel-shaped scapus. Erect secondary clavae. Stylet supports absent.

Type species: Parmursa fimbriata Renaud-Mornant, 1984.

\subsection{Parmursa torquata sp. nov. (Figs 1-4)}

Material: Holotype [slide TAR 690, ZMUC], and 4 paratypes, [slide TAR 691-694, ZMUC] (all males).

Type locality: BIOFAR station $2011\left(61^{\circ} 12.0^{\prime} \mathrm{N}\right.$; $08^{\circ} 31$ W), Faroe Bank, North Atlantic Sea. Depth range: 200 $\mathrm{m}$. The sediment is represented by fine sand, shell gravel, cobbles.

Etymology: From torquis (Latin) twisted collar.

\subsubsection{Diagnosis}

Parmursa with small cylindrical secondary clavae. Primary clavae with a sausage-shaped distal part. A pair 


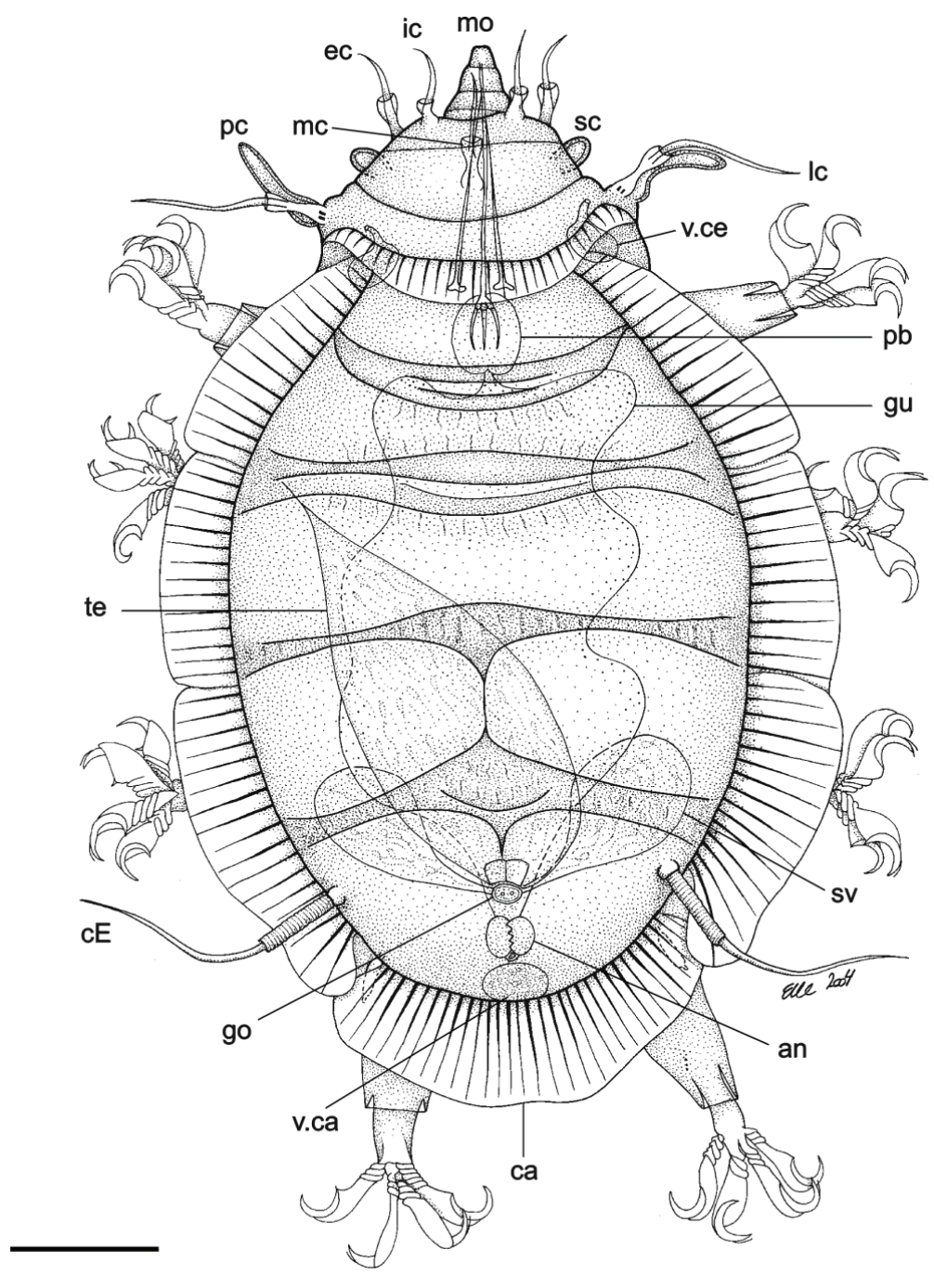

Fig. 2. Parmursa torquata sp. nov.: adult paratypic male, dorsal view. Scale bar $=25 \mu \mathrm{m}$. Drawing by Stine B. Elle.

of cephalic vesicles and a caudal vesicle are present. Lateral alae extending on both sides of the body, from the primary clavae to the fourth pair of legs and a caudal ala extending between the fourth pair of legs. Erect dorsal cephalic ala, extending between the primary clavae. Simple external claws, internal claws with a long dorsal accessory spine.

Holotype: The holotype (Figs 1 and 3) is $142 \mu \mathrm{m}$ long. The body is ovoid, being broadest $(83 \mu \mathrm{m})$ at the level between the second and third pair of legs. The dorsal cuticle has a plated appearance with four transverse inter-segmental depressions: one anterior to the first pair of legs, one between the first and second pair of legs, one between the second and third pair of legs and one between the third and fourth pair of legs (Figs 2 and 4a). An erect dorsal cephalic ala (Figs 2 and $4 \mathrm{a}, \mathrm{b}$ ), two lateral alae (Figs 2 and 4a, c), and a caudal ala (Figs 2 and $4 d$ ) are present. Folds give the impression that each lateral ala is divided into three separate alae, however it is evident using scanning electron microscopy (SEM) that the ala actually is continuous, extending from the primary clava to leg IV. Dorsal cuticular ribs support the alae externally (Fig. 4c).

The trapezoid head (Figs 3b, $d$ and $4 b$ ) is differentiated from the body by the large pedestal of primary clavae and lateral cirri. All the cephalic cirri consist of a cirrophore, funnel-shaped scapus and a flagellar portion. The internal cirri $(17 \mu \mathrm{m})$ arise at the anterior margin of the head. The external cirri $(20 \mu \mathrm{m})$ are inserted ventrally and the median cirrus $(20 \mu \mathrm{m})$ mid-dorsally, anterior to the cephalic ala. The primary clava $(20 \mu \mathrm{m})$ has a swollen proximal part and a sausage-shaped distal part. A Van der Lands's body is visible inside its base. Primary clava and lateral cirrus $(38 \mu \mathrm{m})$ arise separately, on the same pedestal. The secondary clavae are small $(9 \mu \mathrm{m})$ and cylindrical, without an evident cirrophore. They arise ventrally, bending upwards and extend dorsally. The leg I sense organ is an unsegmented spine with a slightly swollen base and a terminal tube. The sense organs of leg II and 

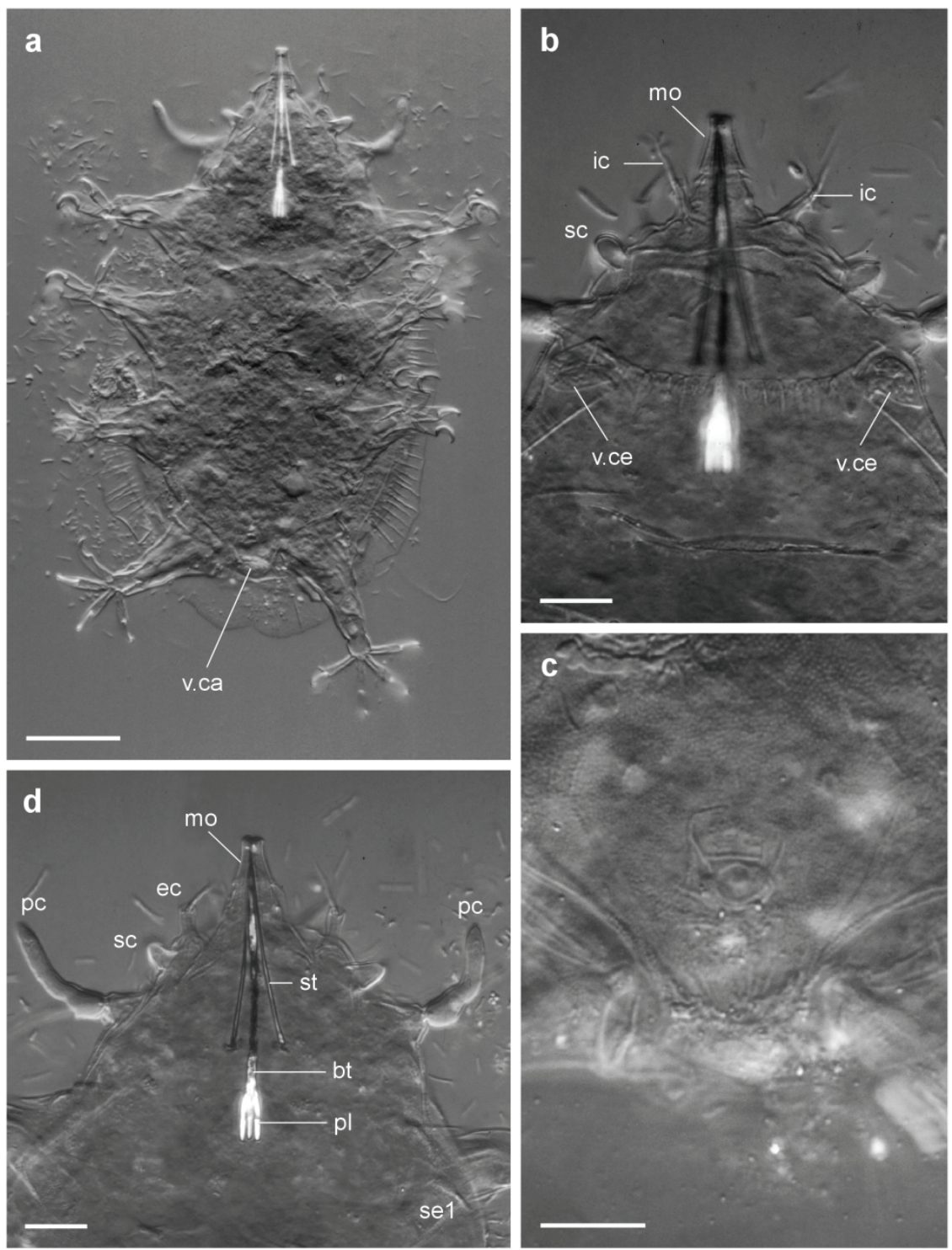

Fig. 3. DIC-micrographs of Parmursa torquata sp. nov., holotypic male. a. Overview. b. Close up on the head, dorsal view. c. Close up on the gonopore. d. Close up on the head, ventral view. Scale bars: $a=25 \mu \mathrm{m}, \mathrm{b}, \mathrm{c}, \mathrm{d}=10 \mu \mathrm{m}$.

III are unsegmented tapering spines. The fourth leg sense organ is an elongate papilla with a basal Van der Lands's body and a terminal tube. The cirrus E $(50 \mu \mathrm{m})$ has a prominent cirrophore, strongly annulated scapus and a long tapering flagellum (Fig. 4d).

A pair of cephalic vesicles and a caudal vesicle are present (Figs 3a and b). The cephalic vesicles open dorsally, and the caudal vesicle opens ventrally. Their function is presently unknown, but their contents look like bacteria, indicating a function similar to the vesicles seen in florarctids (Kristensen 1984).

The leg consists of coxa, femur, tibia and tarsus. Each tarsus bears four digits of equal length. The proximal half of each digit is heavily folded, with each fold extending from a ventral mid-plane to a dorsal midplane. The external claws are simple; the internal claws have a long accessory spine. All the claws can be retracted into claw sheaths.

The mouth cone consists of four parts: a large basal cone, and three telescopic segments. The buccal tube is $39 \mu \mathrm{m}$ long and thin. The stylets are $42 \mu \mathrm{m}$ long and very thin, each with branches of furcae so diverging as to give a rectilinear appearance (Fig. 3d). Stylet supports are lacking. The almost straight placoids are short, thick, and sharply pointed. The pharyngeal apophyses are very small and droplet-shaped. From the pharyngeal bulb, a short oesophagus leads to the diverticulated midgut.

The testis is $68 \mu \mathrm{m}$ long, attached dorsally, at the level between the first and second pair of legs. Two large lateral seminal vesicles are present. The male gonopore is a small protruding cone with an oval 

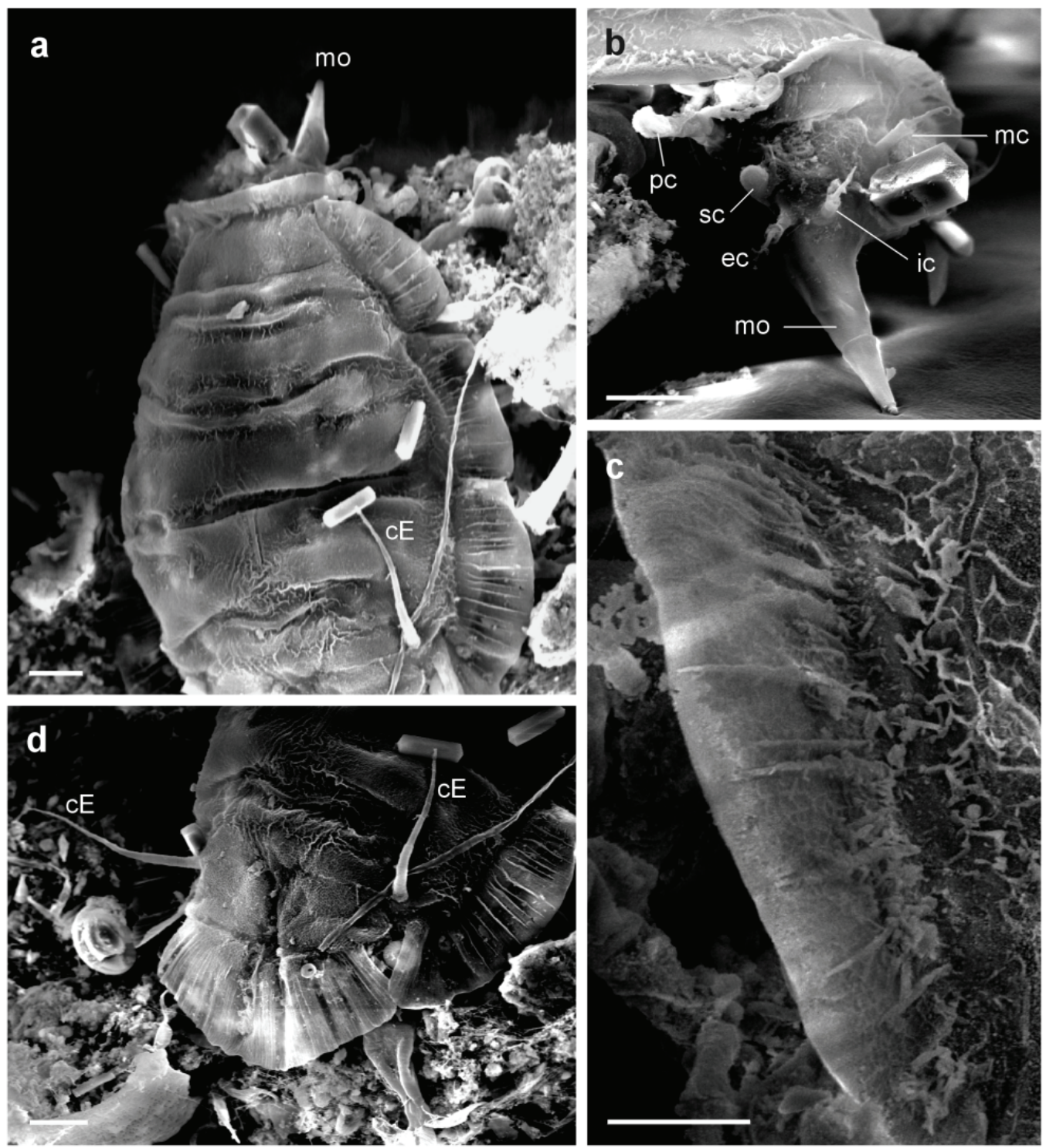

Fig. 4. SEM-micrographs of Parmursa torquata sp. nov. a. Dorsal overview showing the deep depressions of the dorsal cuticle. b. Close up on the head, lateral view, note the almost erect cephalic ala. The large cube is a crystal. c. Close up on the lateral ala with dorsal cuticular ribs. d. Close up on the caudal ala, dorsal view. Scale bars: a, b, d = $10 \mu \mathrm{m}, \mathrm{c}=5 \mu \mathrm{m}$.

opening, with two large pores (openings of the gonoducts), and is situated very close to the anus (Fig. $3 \mathrm{c})$. The anus is closed by a three-lobed cuticular system consisting of two large lateral lobes and a smaller posterior lobe. The anus and gonopore are situated on a large ventral plate (Fig. 1).

\subsubsection{Remarks}

Parmursa torquata sp. nov. can be distinguished from the type species P. fimbriata and Parmursa sp. mainly by its sausage-shaped distal part of primary clavae and its cylindrical secondary clavae without cirrophore. In both P. fimbriata and Parmursa sp., the secondary clavae are strongly ovoid and posses evident cirrophores. The new species also possesses caudal and cephalic vesicles and a large ventral plate. Neither of these structures is evident in P. fimbriata or Parmursa sp. Furthermore, the cephalic ala is smaller in $P$. torquata sp. nov. Using light microscopy, the lateral alae look similar in all three species (they appear divided into three separate alae), but whether the lateral alae of P. fimbriata and Parmursa sp. actually are divided or not, cannot be determined without using SEM-technique. Another interesting feature revealed by the present study, are the dorsal cuticular ribs supporting the alae externally. Describing $P$. fimbriata, Renaud-Mornant (1984) believed these supportive structures to be internal epicuticular pillars. However, again it is evident by using SEM-technique that these 
structures are external cuticular ribs or bars, not internal pillars. This construction is present in all three species of Parmursa but has not been observed in any other arthrotardigrade genera.

\subsection{Family Coronarctidae Renaud-Mornant, 1974}

Arthrotardigrade with cylindrical worm-like body. Trunk cuticle smooth, with folds, bearing three somatic cirri (B, C and E) or only one (E). Eleven cephalic sense organs present, including large flattened secondary clavae (occasionally occurring as indistinct areas). Three or four claws connected to foot by membranes.

Type genus: Coronarctus Renaud-Mornant, 1974.

\subsection{Genus Coronarctus Renaud-Mornant, 1974.}

Diagnosis (emended): Unplated cylindrical body, with more or less pronounced cuticular folds. Three pairs of somatic cirri with accordion-like scapus. Conical head separated into two parts; anterior triangular part with median cirrus and flattened secondary clavae, posterior part narrower, bearing lateral cirri and primary clavae. Four claws on each leg displaying more or less important heterometry. Buccal apparatus without stylet supports or placoids. Digestive tract with poorly developed diverticula. Female with two seminal receptacles.

Type species: Coronarctus tenellus Renaud-Mornant, 1974.

\subsection{Coronarctus verrucatus $s p$. nov. (Figs 5-8)}

In Kristensen (1992, 1999) and Hansen et al. (2001), this species is referred as to Coronarctus stylisetus Renaud-Mornant, 1987. However, a closer examination of the Faroe Bank specimens has led to the recognition of important taxonomic elements that justify the establishment of a new species of Coronarctus.

Material: Holotype [slide TAR 695, ZMUC] and 3 paratypes [slide TAR 696-698, ZMUC] (1 female and two juveniles) from station 627,4 paratypes [slide TAR 699-702, ZMUC] (all females) from station 785.

Type locality: BIOFAR station $627\left(61^{\circ} 17.66^{\prime} \mathrm{N}\right.$; $\left.08^{\circ} 32.25^{\prime} \mathrm{W}\right)$, Faroe Bank, North Atlantic Sea. Depth range: $249-260 \mathrm{~m}$. The sediment type is represented by gravel, shell sand, fine shell sand.

Etymology: from verruca (Latin) wart.

\subsubsection{Diagnosis}

Coronarctus species with slightly reduced stylet-like cephalic cirri and cylindrical torpedo-shaped primary clavae. Secondary clavae with a narrowing indentation of the posterior ventral lobes. Cuticle studded with numerous small wart-like excrescences. Sense organs present on each pair of legs. Large spine-like process on leg IV. Equally sized and shaped claws, all with a long, fine accessory spine.

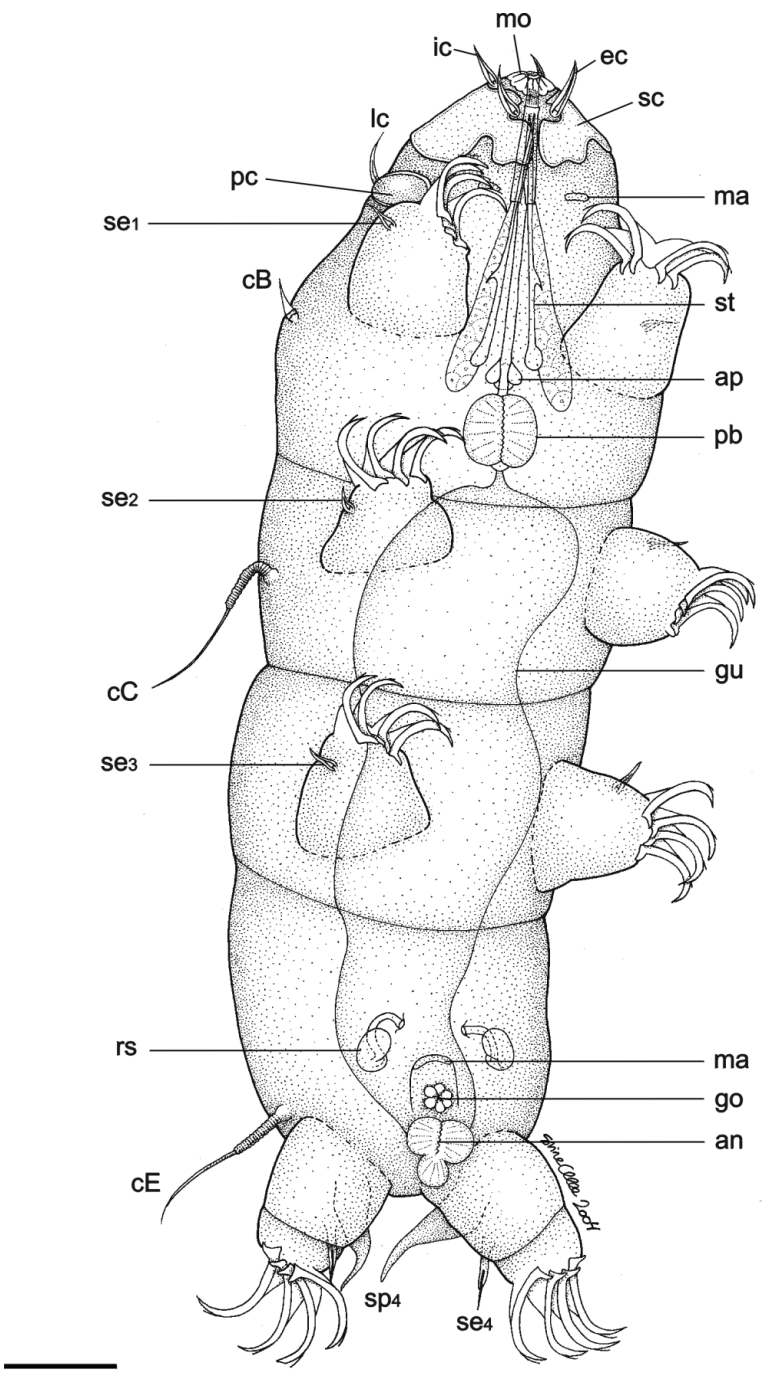

Fig. 5. Coronarctus verrucatus sp. nov.: adult holotypic female, ventral view. Scale bar $=25 \mu \mathrm{m}$. Drawing by Stine B. Elle.

Holotype: The holotype (female) (Figs 5, 6a, c and 7c) is $256 \mu \mathrm{m}$ long and $90 \mu \mathrm{m}$ wide. The body is elongate, cylindrical with a constriction between each pair of legs. The cuticle is very unusually sculptured, with numerous small wart-like excrescences, regularly distributed all over the animal like rivet heads in a metal plate (Fig. 8a). Only the cirri, gonopore and anus areas are devoid of this sculpture. The head is well differentiated, being narrower than the body. The anterior conical part of the head bears the external $(13 \mu \mathrm{m})$ and internal cirri $(11$ $\mu \mathrm{m})$, median cirrus $(11 \mu \mathrm{m})$ and the secondary clavae. The posterior cylindrical part of the head bears the primary clavae $(12 \mu \mathrm{m})$ and lateral cirri $(15 \mu \mathrm{m})$. Midventrally, at the level of the primary clavae, two large, rectangular muscle attachments are evident. The torpedo-shaped primary clava is inserted dorso-laterally and lies on the side, embedded into a socket (Figs 6 and 8a). Lateral cirrus and primary clavae are inserted separately, but close together. 


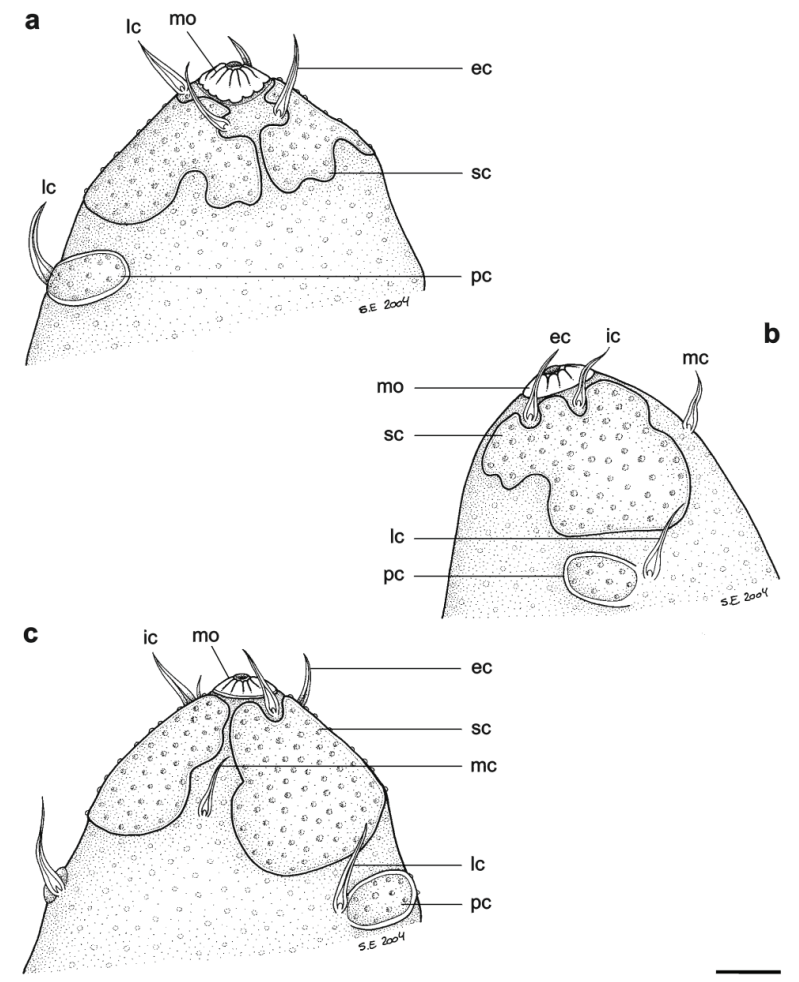

Fig. 6. Coronarctus verrucatus sp. nov.: a. Semi-ventral view of the head of the adult holotypic female. b. Lateral view of the head of an adult paratypic female. c. Semi-dorsal view of the head of the adult holotypic female. Scale bar $=10 \mu$ m. Drawings by Stine B. Elle.
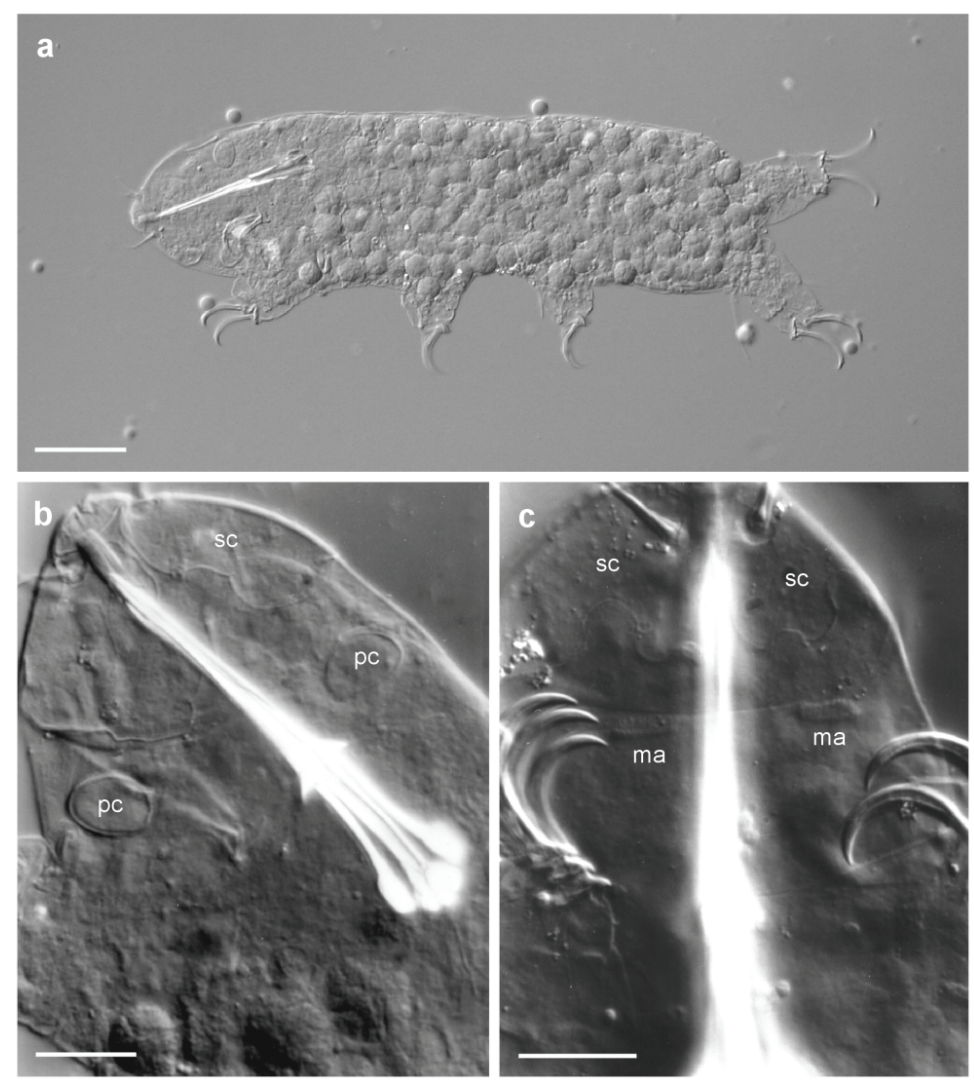

Fig. 7. DIC-micrographs of Coronarctus verrucatus sp. nov. a. Lateral overview of a two-clawed larva. b. Close up on the head of the two-clawed larva. c. Close up on the head of the holotypic adult female. Scale bars: $\mathrm{a}=25 \mu \mathrm{m}, \mathrm{b}, \mathrm{c}=10 \mu \mathrm{m}$ 

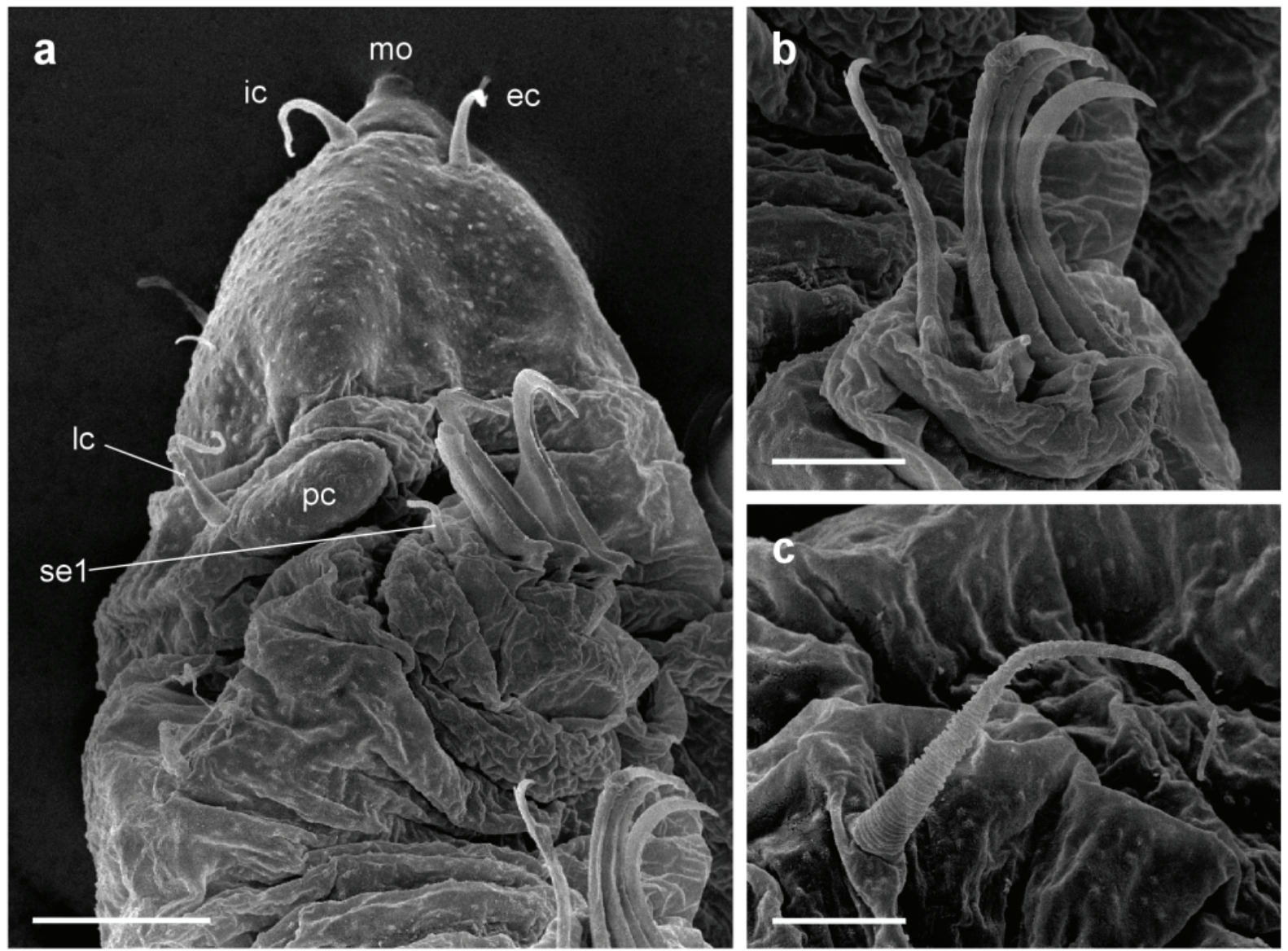

Fig. 8. SEM-micrographs of Coronarctus verrucatus sp. nov.: a. Lateral overview of the head, note the peculiar sculpture of the cuticle. b. Close up on claws of leg II, note the modified number (5) of claws. This number is a specific case of this specimen and only on this leg. c. Cirrus C. Scale bars: $\mathrm{a}=10 \mu \mathrm{m}, \mathrm{b}, \mathrm{c}=5 \mu \mathrm{m}$.

The flattened secondary clava consists of four lobes and extends from a mid-ventral position to a mid-dorsal position (Fig. 6). The cephalic cirri and the sense organs of leg pair I-III all have the same configuration being stylet-shaped and with a very refractive and nonprotruding internal sensory structure. The sense organ of leg IV appears more rigid and spine-like and its needlelike sensory structure is only partly embedded in the spine and partly protruding. A large $(31 \mu \mathrm{m})$ spike-like process is inserted dorsally on the coxa of leg IV. Cirrus $\mathrm{B}$ is small and similar in shape to the cephalic cirri, however it has a basal wrinkle and lacks the internal refractive sensory structure. Cirri C (Fig. 8c) and E are identical, with a distinct cirrophore, accordion-like scapus and a long, tapering flagellum.

The first three pairs of legs are stumpy, whereas the fourth pair is a little longer. Four claws, equal in size and shape, are inserted on each leg. All the claws have a long, fine accessory spine (Fig. 8b).

The mouth opening is terminal and surrounded by twelve cuticular folds. The buccal tube is $72 \mu \mathrm{m}$ long and has three very large droplet-shaped apophyses anterior to the pharyngeal bulb (Fig. 7b). They are inserted on the buccal tube, in a $120^{\circ}$ angle to each other; two ventro-lateral and one mid-dorsal, and have a cuticular lining which is evident after the $\mathrm{CaCO}_{3}$ has been dissolved. The pharyngeal bulb is devoid of placoids. The stylets are $59 \mu \mathrm{m}$ long with, at midlength, a prong-like structure, and enlarged proximally into elongate bulb-shaped furca. Stylet supports are lacking. The midgut is slender, slightly sinuous, and without pronounced diverticula. The anus is a highly refractive serrated slit, surrounded by three lobes of wrinkled cuticle. A large, rectangular muscle attachment is present anterior to the six-plated rosette gonopore. The two cuticular seminal receptacles each consist of a two-lobed pouch and a curving duct bending toward the gonopore.

Juvenile: The two-clawed larva (Figs 7a and b) is 178 $\mu \mathrm{m}$ long. The body is elongate, cylindrical without constrictions between each pair of legs. The primary clavae is not as elongate as in the adult. Two claws on each leg, with a short accessory spine. The large spikelike process of leg IV in the adult, is not fully developed in the larva, and appears as a short conical process. The midgut is large, occupying the body completely, and is filled with large spheroids. Anus and gonopore are 
absent. In all other features, the larva is similar to the adult.

\subsubsection{Remarks}

Coronarctus verrucatus sp. nov. is closely related to Coronarctus stylisetus Renaud-Mornant, 1987 and Coronarctus fastigus Renaud-Mornant, 1987 by claw shape and size (displaying claw homometry) and by the presence of a long spine-like process on leg IV. However, two main features distinguish Coronarctus verrucatus sp. nov. from $C$. stylisetus and C. fastigus. The primary clavae of the new species are larger, not pedunculate, and without a pedestalate socket. The dorsal and ventral lobes of the secondary clavae also have a shape different from $C$. stylisetus and $C$. fastigus. A unique feature of Coronarctus verrucatus sp. nov., is the global cuticular sculpture, not shared with any other congeneric species.

\section{CONCLUSION}

The finding of two new species of Parmursa further consolidates the former monotypic genus. Furthermore, Parmursa torquata sp. nov. at the Faroe Bank and the single specimen of Parmursa sp. at Lihir Island in the New Ireland Basin, greatly widens, not only the depth range of the genus Parmursa (200-1813 m), but also the geographic distribution of this genus. Being present in the North Atlantic Ocean, Indian Ocean and IndoPacific Ocean, the genus Parmursa shows a circumglobal distribution, although it seems restricted to bathyal depth. The presence of Coronarctus verrucatus sp. nov. in the relatively shallow water of the Faroe Bank (249-260 m) further widens the depth range of Coronarctus species distribution $(249-4690 \mathrm{~m})$. The new species $C$. verrucatus sp. nov. belongs to the group of three Coronarctus species, displaying claw homometry. Interestingly, these three species - $C$. verrucatus sp. nov. (249-260 m), C. stylisetus $(439 \mathrm{~m})$ and $C$. fastigus $(675-2400 \mathrm{~m})$ - also show a tendency towards a bathyal rather than an abyssal distribution. As Coronarctus tenellus Renaud-Mornant, 1974 (16304690 m), Coronarctus disparilis Renaud-Mornant, 1987 (3400 m) and Coronarctus laubieri Renaud-Mornant, 1987 (1700-4140 m) display claw heterometry as well as an abyssal distribution, two evolutionary lines are indicated both by claw morphology and depth distribution.

\section{ACKNOWLEDGMENTS}

I am indebted to Reinhardt Møbjerg Kristensen who has facilitated the collection of tardigrades at the Faroe Bank. Stine B. Elle, employed by the Carlsberg Foundation, is thanked for her beautiful and accurate drawings of both Parmursa torquata sp. nov. and Coronarctus verrucatus sp. nov. Aslak Jørgensen is warmly thanked for assistance with preparing specimens for scanning electron microscopy. The Muséum National d'Histoire Naturelle, (Paris) has generously provided the loan of the type species of Parmursa fimbriata and Gunnar Gad has facilitated the loan of tardigrade specimens collected at Lihir Island.

\section{REFERENCES}

Hansen, J.G. 2005. The ongoing investigation of the Faroe Bank Tardigrade fauna. Frodskaparrit supplementum: Proceedings from the BIOFAR Symposium, Tórshavn, Faroe Islands, 24.- 26. April 2003, North-East Atlantic marine benthic organisms in the Faroes - taxonomy, distribution and ecology: 220-223.

Hansen, J.G., A. Jørgensen, \& R.M. Kristensen. 2001. Preliminary studies of the tardigrade fauna of the Faroe Bank. Zool. Anz., 240: 385-393.

Herzig, P.M. 1998. Cruise report "SONNE 133" (BMBF FK 03G0133A) volcanism, hydrothermal processes and biological communities at shallow submarine volcanoes of the New Ireland Fore-Arc (Papua New Guinea). Technische Universität Bergakademie, Freiberg, Germany.

Kristensen, R.M. 1984. On the biology of Wingstrandarctus corallinus nov. gen., nov. spec., with notes on the symbiontic bacteria in the subfamily Florarctinae (Arthrotardigrada). Vidensk. Meddr. dansk naturh. Foren., 145: 201-218

Kristensen, R.M. 1992. The meiofauna of Faroe Bank. Symposium on Marine Biology and Oceanography of the Faroe Islands, Norđurlandahúsiđ i Føroyum, Árbók 199192: 86-87.

Kristensen, R.M. 1999. Ten years investigation of a sunken Atlantis: the meiofauna of Faroe Bank. Danish national council for Oceanology, Norske havforskeres forening, Svenska havforskningsforeningen. $2^{\text {nd }}$ Nordic marine science meeting, 2-4 March, 1999, Abstract book: 58-59.

Nørrevang, A., T. Brattegard, A.B. Josefson, J.-A. Sneli \& O.S. Tendal. 1994. List of BIOFAR stations. Sarsia, 79:165-180.

Renaud-Mornant, J. 1984. Halechiniscidae (Heterotardigrada) de la campagne Benthedi, Canal de Mozambique. Bull. Mus. natn. Hist. nat. Paris., 6: 67-88.

Renaud-Mornant, J. 1987. Bathyal and abyssal Coronarctidae (Tardigrada), description of new species and phylogenetical significance. In: R. Bertolani (Ed.), Biology of Tardigrades. Selected Symposia and Monographs U.Z.I. 1. Mucchi Editore, Modena, Italy: 229-252. 